\title{
Reciprocal Disclosure in Criminal Trials: \\ Stacking the Deck Against the ACCused, or Calling Defence Counsel's Bluff?
}

\author{
BRIAN EDWARD MAUDE
}

The author discusses the effect reciprocal disclosure would have on the accused's right to remain silent and the right not to incriminate oneself. As these rights are strongly entrenched in Canada's judicial system, the author examines if there is room to incorporate defence disclosure into Canada's criminal trial proceedings. A review is made of other jurisdictions where some degree of reciprocal disclosure is in place, and the limitations of introducing similar procedures into the Canadian system are discussed. The author concludes that the introduction of reciprocal disclosure would be a moderate expansion of already existing notice requirements, and defence counsel should start to introduce their own guidelines with respect to defence disclosure.
L'auteur étudie l'effet que la divulgation réciproque aurait sur le droit au silence et la protection contre l'auto-incrimination de l'accusé. Ces droits étant solidement ancrés dans le système judiciaire canadien. l'auteur se demande s'il est possible d'inkégrer la divulgation de la partie defenderesse dans la procédure en matiere criminelle. II passe en revue les régimes autorisant une certaine mesure de divulgation réciproque et explique en quoi il convient de limiter ces pratiques au sein du système canadien. II conclut que l'adoption de la divulgation réciproque constituerait une amplification modérée de l'obligation de notification deja en vigueur et qu il incombe aux avocats de la defense de commencer $\dot{a}$ instituer leurs propres directives à cet égard.

\section{TABLE OF CONTENTS}

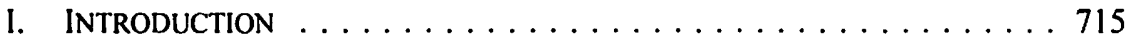

II. ThE RIGHT to SILENCE - "Shut UP or PUT UP" . . . . . . 716

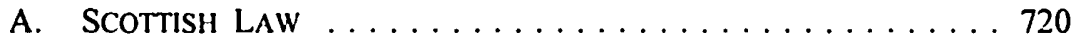

B. DID YOU SAY "DisclosURE" OR "NOTICE"? . . . . . . . . . 720

III. SELF-INCRIMINATION: "WAS IT SOMETHING I SAID?" . . . . . . . 723

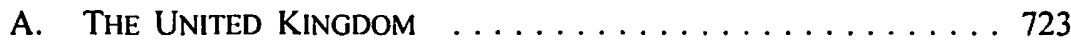

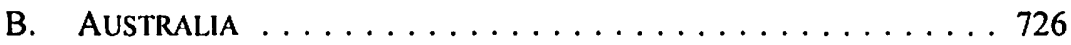

C. THE United States of AMERICA . . . . . . . . . . . . 727

IV. Conclusion: Proposals for DEFEnCE Disclosure . . . . . . . 733

\section{INTRODUCTION}

William B. Stinchcombe, Appellant, versus Her Majesty The Queen, Respondent. Regina versus Stinchcombe.' It is a name that has become famous to defence counsel across Canada and equally infamous to Crown Prosecutors. It is repeated over and over as mantra by those whose chosen profession is the legal defence of people accused of criminal activity. "Your Honour, my friend has not complied with his/her obligations under Stinchcombe." It has almost a frat-house paddle effect to Crown Prosecutors. It is a name that stands for the compulsory disclosure by the Crown, to the defence, of all the evidence, in the Crown's possession or control, relevant to the accused's case. 
Inasmuch as Stinchcombe disclosure is seen as a bane to Crown counsel, any hint of reciprocating the disclosure obligation draws nothing less than howls of protest from the defence bar. Is this due to the concept of what represents "disclosure by the defence" to the defence, or is this due to the nature of the word "disclosure"? It will be shown that defence counsel frequently disclose numerous things to their counterparts in the Crown's office: formal notice of certain defences and applications, informal notice of witnesses and defences at pre-trial hearings.

Disclosure by the Crown has been argued to be a necessary requirement in order to "level the playing field" between an accused of limited means and the seemingly "limitless" resources of the government. It is also to avoid "trial by ambush" by the Crown - to give the accused all the evidence that is to be used against him or her so that he or she can make full answer and defence and not be surprised by elements of the Crown's case.

The following analysis is about giving adequate information to both sides: reciprocal disclosure. This is a process that is currently being used in common law jurisdictions around the world: England, Scotland, Australia and several of the states in the United States. It requires the defence to disclose to the Crown (or Prosecution) certain elements of the case that it plans to present at trial. These elements include names of defence witnesses, their addresses, and sometimes their statements. It also, in some jurisdictions, can go as far as a statement by the accused made at arrest or during a subsequent interview by the Crown. The penalty for failure to comply with these rules of disclosure runs the gamut from reducing the weight given the evidence, to the drawing of an adverse inference against the accused, to outright exclusion of the evidence as inadmissible.

Canada is now one of the last remaining English common law jurisdictions without reciprocal disclosure rules or guidelines. Several authors have recently commented on defence disclosure in Canada; these studies have provided much of the foundation for this analysis. Reference will be made, therefore, to these studies, and their conclusions will be analyzed and critiqued. The primary focus of this study, however, will remain focused on defence disclosure in Canada - jurisprudence that seems to either permit defence disclosure, encourage it, or open a door that may eventually lead to it. Reference will be made to other common law jurisdictions, and the examples taken from these areas will be held up to the light of the Canadian Charter of Rights and Freedoms to question their possible applicability to the Canadian system. Finally, potential avenues of defence disclosure will be explored, particularly with respect to an eventual imposition of requirements or rules in this area, and how this may be achieved.

\section{The Right to Silence - "Shut UP OR PUt UP"}

Stinchcombe is seen as a watershed in Canadian criminal jurisprudence. It is now formally required that the Crown provide the defence with all "material [...] not only that which the Crown intends to introduce into evidence but also that which it does not" and that "no distinction should be made between inculpatory and exculpatory evidence." This is done so that the accused is capable of making "full answer and 
defence" to the charges that he or she is facing. The accused has no duty to say or do anything; in fact, the accused has the right to not say or do anything. This right, however, is not absolute.

One example of a narrowing of this right is that the accused is "required" to provide "timely and adequate" disclosure of an alibi defence to the Crown. This is done, in the words of Iacobucci J. of the Supreme Court in $R$. v. Cleghorn, as "a rule of expediency intended to guard against surprise alibis fabricated in the witness-box which the prosecution is almost powerless to challenge." ${ }^{3}$ As a result, timely disclosure allows for investigation of the alibi by the police. The argument that the overwhelming resources of the Crown far outweigh those of the accused (and that this would in some way prejudice the accused) was not addressed by their Lordships in their decision. This is understandable: if the seemingly limitless resources of the State were used to corroborate the alibi of the accused, this information would have to be disclosed to the defence. This would hardly be an undesirable result from the point of view of defence counsel. If, therefore, disclosure of an alibi defence is not repugnant to the rights of the accused, why would disclosure of any other defences, particularly "special defences" such as automatism, insanity or, intoxication, be any more violative of these same rights?

One of the many arguments used to oppose defence disclosure is that it is a violation of the accused's right to pre-trial silence as guaranteed by the Charter. ${ }^{4}$ One of the main cases used to define the "right to silence" is Thomson Newspapers Ltd. v. Canada. ${ }^{5}$ In his article against defence disclosure, ${ }^{6}$ Charles B. Davison, relying upon the principles established in Thomson, says that

[u]nder our system of law - and in our society generally - there is no broad legal duty upon any citizen to assist or cooperate with police or any other agency of the statc. As a matter of basic principle, each one of us has the fundamental right to be left alone by the forces of the state, subject only to very narrow and particular positive duties which might be imposed from time to time by Parliament.?

This is an interesting viewpoint. Davison seems to be bringing the adversarial system out of the Courtroom and squarely into society at large. Taken to an extreme, it could, under his vision of the "right to silence," become increasingly difficult to prosecute crimes in a society where citizens stubbornly insist upon their lack of a duty to cooperate with police. Witnesses would be impossible to subpoena as they would have

$2 \quad$ R. v. Cleghorn (1995), 100 C.C.C. (3d) 393 (S.C.C.) [hereinafter Cleghorn].

Ibid. at 397.

$4 \quad$ See R. v. Hébert (1990), 57 C.C.C. (3d) 1 (S.C.C.) [hereinafter Hébert], and Thomson Newspapers Lid. v. Canada (Director of Investigation \& Research, Restrictive Trade Practices Commission) (1990), 54 C.C.C. (3d) 417 (S.C.C.) [hereinafter Thomson] with respect to the "right to silence" and the Charter.

Thomson, ibid.

" C.B. Davison, "Putting Ghosts to Rest: A Reply to the "Modest Proposal" for Defence Disclosurc of Tanovich and Crocker" (1995), 43 C.R. (4th) 105.

I Ibid. at 113. 
no duty to cooperate with the Crown, an "agency of the state." This extreme is, of course, highly unlikely, but it does call into question the limits of the "right to silence."

Davison criticizes the stand taken by David Tanovich and Lawrence Crocker in their article $^{8}$ with respect to the right to silence, saying that they reduce it to "suspects in detention" and that it is, in their view, a "personal right [which would] not [be] compromised by requiring the defence to produce the names and statements of third parties it intends to call to testify." ${ }^{10}$ Davison disagrees with these limitations. The Supreme Court, however, may not. Despite Davison's protests to the contrary, the Court in Hébert clearly addressed the ambit of the "right to silence" in the context of a right belonging to a "detained person."

Furthermore, in Thomson, there were five separate judgements rendered on the scope of section 7 of the Charter as it respects sections 11(c) (the right of an accused not to be compelled to testify against him or herself) and 13 (the right against selfincrimination). Mr. Justice Sopinka stated that it represented the right to remain silent; Mr. Justice Lamer felt it accorded a right not to give an incriminating answer; Madame Justice Wilson would extend the right to mean the exclusion of compelled testimony from all subsequent proceedings against the accused; Mr. Justice La Forest would limit the exclusion to only that derivative evidence not otherwise discoverable apart from the accused's compelled testimony; and Madame Justice L'Heureux-Dubé found that section 7 accorded no additional right to sections 11 (c) and 13." This would appear to render the "right to silence" a little less clear than Davison would have it stated. What is clear, however, is that the "right to silence," as articulated by the Supreme Court in both Hébert and, subsequently, in $R$. v. Crawford, ${ }^{12}$ is not absolute.

In Hébert, the "right to silence" was not found to override the "confessions rule," provided the confession was obtained in a manner that did not infringe the rights of the accused..$^{13}$ Moreover, the court found that the application of the "right to silence" to the "confessions rule" only applied to the accused once he or she was detained, and that the "right to silence" did not extend to "pre-detention investigations." There is, however, quite a leap to be made between "pre-detention investigations" and disclosure of the defence's case.

Can defence disclosure automatically be seen as a "confession"? Given the presumption of innocence, this would seem unlikely. Notwithstanding that presumption,

x D.M. Tanovich \& L. Crocker, "Dancing with Stinchcombe's Ghost: A Modest Proposal for Reciprocal Defence Disclosure" (1994), 26 C.R. (4th) 333.

Ibid. at 341.

lbid.

Taken from P.W. Hogg, Constitutional Law of Canada 3d ed. (Toronto: Carswell, 1992) at 1037. (1995), 96 C.C.C. (3d) 481 (S.C.C.).

Supra note 4 at 13. Their Lordships did not go into too much detail in this regard. They did address the use of police informants in jail cells, stating that, in some situations, this could be violative of the accused's right to pre-trial silence. However, they also concluded that a violation would not automatically exclude any statement so obtained; it would first be necessary to address its admissibility under section 24(2) of the Charter. 
whatever materials the defence provides to the Crown, they would undoubtedly be used against the accused at trial. It would therefore stand to reason that the right to silence could not apply to defence disclosure were it optional. Should the accused invoke his or her right to silence and provide no materials to the Crown, no adverse inference could then be drawn from the exercise of that right. ${ }^{14}$ The accused could then not be forced to make disclosure when he or she chooses to remain silent. The question then becomes does this silence preclude the defence from putting on a case? The accused has a right to make full answer and defence to the charges against him or her. Does the accuse waive the positive exercise of that right by choosing to remain silent? Probably not. This could prove inherently unfair to the accused. What would occur if the Crown uncovers new evidence during the trial that would change the nature of the defence strategy? The accused could not fairly be precluded from re-evaluating his or her plan and then deciding to present an affirmative defence. The weight of the accused's defence could be diminished by late disclosure, but under the circumstances just outlined, this would be too prejudicial to the accused.

However, were the accused to refuse to disclose any information prior to trial (after having received disclosure from the Crown), and then subsequently insist on presenting an affirmative defence, less weight could be given to the defence without prejudice to the accused. The accused was aware of the Crown's case; presuming an accused with legal representation, he or she has already conferred with counsel with respect to the strengths and weaknesses of the evidence. Assuming the existence of a scheme of mandatory, limited defence disclosure (e.g. providing a list of possible defences as well as the names and addresses of any defence witnesses to be called at trial), the accused could refuse to provide such information to the Crown, exercising his or her right to pre-trial silence. Once the trial has begun, any decision by the accused to present an affirmative defence to the charges by calling witnesses would result in less weight being attached to the defence due to lack of pre-trial disclosure. Would this prejudice the accused or not? The accused's defence has been accorded less weight, but the Crown still has to overcome the hurdle of proving the accused's guilt beyond a reasonable doubt. Again, no adverse inference has been drawn; the accused is still innocent of the charges.

It would sometimes be difficult to disclose the names of witnesses to be called by the defence. In addressing the issue of defence disclosure in the United Kingdom, the Royal Commission on Criminal Justice (1993) "recommended against requiring defence counsel to disclose the names [...] of the witnesses to be called because (i) such decisions are often made in the course of the trial, and (ii) it could give an advantage to the Crown where the prosecution called a defence witness that the defence had decided not to call."15 This is certainly a possible disadvantage to the accused. However, could it be overcome by the timing of disclosure?

is G.D. McKinnon, "Accelerating Defence Disclosure: A Time for Change" (1996) 1 Can. Crim. L.R. 59 at 62. 
If defence counsel were required to provide such a list to the Crown one week prior to trial, would it be reasonable to presume that the Crown would be able to investigate and examine all of the defence's witnesses prior to commencing their case? Given the current state of the Crown's workload (particularly in Alberta), this is unlikely. Disclosure then becomes a question of timing. This time line is similar to the current situation in Scotland.

\section{A. SCOTtish LAW}

Under Scottish law, defence counsel must disclose, ten days prior to the commencement of trial, any plea of a special defence. ${ }^{16}$ Three days prior to trial, "the defence must provide the prosecution with a list of the defence witnesses." ${ }^{17}$ Scottish law goes further than this, though; there is also a provision that the accused may be required to submit to an examination, in the presence of counsel, by the prosecutor. ${ }^{18}$ According to McKinnon, the holding of this "judicial examination" serves three purposes:

- to permit the accused an early opportunity to challenge the prosecution's case and to state his or her position in relation to the charge;

- to give the prosecution an early opportunity to hear the accused's explanation and to prevent subsequent fabrication of false defences; and

- to allow the accused an opportunity to challenge the accuracy or fairness of alleged statements obtained by the police."

Such a situation would, in Canada, be a serious infringement of an accused's right to pre-trial silence. Routinely, upon arrest, an accused is informed of his right to counsel, along with the caveat that anything he or she may say, after being informed of this right, may be taken down and used against the accused at trial. It would stand to reason that any obligation imposed upon an accused to submit to questioning by the Crown (in the presence of counsel or not) would contradict the exercise of this right.

\section{B. Did You SAY "Disclosure" OR "NOTICE"?}

The right to pre-trial silence is one of the standards that has been raised to combat the notion of defence disclosure. Given the existence of certain practices in criminal trials, is it the concept of disclosure that is causing the protests, or is it the term "disclosure"? In opposition to the concerns over defence "disclosure," it would appear that there are no great concerns (at least none on the scale of the anti-defence disclosure

Ibid. McKinnon lists "special defences" as: alibi, insanity, automatism, identification and selfdefence.

17 Ibid.

1* Criminal Justice (Scotland) Act 1980 (U.K.), 1980, c. 62, s. 20^, as referred to in McKinnon, supra note 15.

1" A.J. Ashworth, "Some Blueprints for Criminal Investigation" (1976) Crim.L.R. 594 at 601. 
articles) with respect to notice being given by the defence with respect to several aspects of the defence's case. There exist, in Canada, few requirements of defence "disclosure" but there are, however, several requirements with respect to defence "notice."

Notice is required with respect to a number of actions of defence counsel, either in preparation for trial or at the trial itself. Under sections 276 and 276.1 of the Criminal Code, the defence is required to provide written notice, in advance, to the prosecutor and to the clerk of the court of any intention to cross-examine a complainant (in a sexual assault or related charge) on his or her previous sexual activity. This section has been in force since 1992 and has never been struck down as unconstitutional.

Also, defence counsel is statutorily required to provide fourteen days written notice to both the Attorney General for Canada and the Minister of Justice and Attorney General for Alberta if and when he or she plans to contest the constitutional validity of legislation. ${ }^{20}$ The result, if the legislation were to be judged unconstitutional, would be that the accused would likely be acquitted. Is this not a form of defence? The Canadian Law Dictionary defines "defence" as "a denial, answer or plea [...] opposing the truth or validity of [...] the charge against the accused." ${ }^{21}$ Black's Law Dictionary defines "defence" as "[t]hat which is offered and alleged by the party proceeded against in an action [...] as a reason in law or fact why the plaintiff [prosecution] should not recover or establish what he seeks." 22

If a "tactic" - challenging the constitutionality of legislation - achieves the same result as a standard "defence," does it not then qualify as a defence? Furthermore, if defence counsel is required to give notice to, in effect, "disclose" its intention to challenge the constitutional validity of the legislation forming the basis of the charge against the accused, is this notice not, in essence, written defence disclosure of its defence, fourteen days prior to trial?

The requirement of notice with respect to constitutional matters does not stop with challenging the validity of legislation. It has also been applied to the raising of a Charter-based defence. In the decision of the Alberta Court of Appeal in $R$. v. Dwernychuk, ${ }^{23}$ their Lordships felt that a reasonable person would expect the defence to give notice of its intention to challenge the admissibility of certain pieces of evidence under the Charter. The Court concluded that:

Section 25(1), Judicature Acl, R.S.A. 1980, c. J-I, s. 25 which reads: "If in a procceding the constitutional validity of an enactment of the Parliament of Canada or of the Legislature of Alberta is brought into question, the enactment shall not be held to be invalid unless 14 days' written notice has been given to the Attorney General for Canada and the Minister of Justice and Attorney General for Alberta."

21 J.A. Yogis, Canadian Law Dictionary, 3d ed. (Toronto: Barron's, 1995) at 66.

22 J.R. Nolan \& J.M. Nolan-Haley, Black's Law Dictionary, abridged 6th ed. (St. Paul: West Publishing Co., 1991) at 290.

27 R. v. Dwernychuk (1992), 77 C.C.C. (3d) 385 (Alta.C.A.) [hereinafler Dwernychuk]. 
Such a reasonable person would expect that where the defence intends to raise a Charter issue and seek the exclusion of evidence, the procedure followed would be such as to give the Crown and the judge reasonable notice of the intention to do so.... [T] he defence need not disclose what evidence of fact or opinion it intends to adduce. This, it is thought, is a rule which at least in part matches the investigative and prosecutorial powers of the prosecution. However, when it comes to an issue of the exclusion of evidence where there has been an infringement of a Charter right, no similar established rule exists. ${ }^{24}$

In Dwernychuk, the accused was challenging the admissibility of breathalyzer results taken at the time of his arrest. He was not claiming that he did not drive his vehicle, nor did he offer testimony that he was not over .08 at the time he was driving. He was challenging the admissibility of the evidence presented against him with the eventual result that, were it excluded, he could be acquitted for lack of evidence. Is this not, in essence, the desired result of a defence? Dwernychuk was not heard at the Supreme Court of Canada. ${ }^{25}$ If reasonable "notice" of a Charter "defence" is acceptable, why, then, is reasonable "notice" of a common law or statutory defence repugnant? The Alberta Court of Appeal held that such notice of a Charter application

...enables Crown counsel to prepare legal submissions in advance rather than hastily and on the spur of the moment. It enables the judge, with the help of both counsel, to begin to read relevant cases and to put his or her thoughts in order, rather than becoming aware of the existence and nature of a Charter issue only after he or she has heard the evidence without realizing what he or she should be listening for and without being able to exercise his or her limited right to ask questions of witnesses. If such notice is given, the judge is better able to reach a rational decision which is based on a calm reading and serene application of the law, rather than having to reach a decision, perhaps without duc consideration, because of the inexorable pressure of his or her docket. ${ }^{26}$

Why, then, should this consideration be abandoned when it comes to notice of other, non-Charter defences? Granted, Charter arguments can be very complex and require much preparation and argument, but it can be argued that, similarly, so do many defences. The complex defence of intoxication was only recently addressed in much detail with respect to certain specific intent offences in a trilogy of cases at the Supreme Court. ${ }^{27}$ Any consideration of this defence cannot be accomplished lightly. How, then, does this differ from a Charter application? One could submit that it does not. The preparation of complex arguments by both defence and Crown counsel, and their presentation of these arguments before an informed, prepared judge in a Charter application, would be no different from equally prepared counsel presenting a complex defence before that same judge. If notice of one "defence" is acceptable and fair to the accused, so too would be notice of the other.

2s $R$ v. Dwernychuk, application for leave to appeal dismissed (without reasons), [1993] S.C.C.A. No. 30 (QL).

26. Dwernychuk, supra note 23 at 393.

$27 \quad$ R. v. Robinson (1996), 105 C.C.C. (3d) 97 (S.C.C.); R. v. McMaster (1996), 105 C.C.C. (3d) 193 (S.C.C.); and R. v. Lemky (1996), 105 C.C.C. (3d) 137 (S.C.C.). 
Consequently, disclosure of special defences (or, indeed, any defences) does not appear to contradict the right of the accused to remain silent as the accused is not "saying" anything and is not required to testify. To offer a simple example, giving notice to the Crown of the fact that an accused shoplifter will be challenging the existence of the mens rea element of the offence hardly seems to fly in the face of the pre-trial right to silence in the same way that notice of an intention to exclude evidence obtained in a possibly unreasonable search does not do so. The pertinent right is then, perhaps, not the "right to silence," but the right against self-incrimination. The question to be asked should then be one of the quality of the evidence that the accused is providing the Crown, and not the mere fact that he or she is providing it.

\section{SELF-INCRIMINATION: "WAS IT SOMEThING I SAId?"}

In the same way that alibi evidence is seen as an exception to the accused's right to silence, defence disclosure of certain materials could be seen as an exception to the accused's right against self-incrimination. However, this would seem to pose a more complex and sensitive problem: the accused cannot be compelled to, in essence, "testify" against him or herself. Disclosure of planned defences could result in this taking place. For example, in advancing an automatism defence, the accused is admitting that he committed the crime. He or she is then seeking to have this criminal behaviour excused by calling into question the existence of the mens rea portion of the offence. In Canada, there is currently no requirement on the part of the accused to disclose the intention to lead this defence at trial.

\section{A. THE UNiTED KINGdOM}

In the United Kingdom, however, there is such a requirement. In 1987, Westminster passed the Criminal Justice Act $1987^{28}$ which establishes that,

[O]nce the defence has received preliminary disclosure from the Crown, a trial judge at a preparatory hearing may order the defence to give to the court and the prosecution a statement setting out in general terms the nature of the defence, the parts of the Crown's case objected to, and any questions of law which will be raised. ${ }^{29}$

Under such a scheme, the defence would then be required to give advance notice of their intention to raise a specific defence when the accused is involved in a serious fraud case. According to section 81 of the Police and Criminal Evidence Act 1984, the defence is also required to give advance notice of any expert evidence that it plans to adduce. ${ }^{30}$ This requirement, however, is reciprocal: both Crown and defence must give advance notice of any experts. As it was set out in the $1987 \mathrm{Act}$, serious fraud cases were the only situation requiring such disclosure. This, however, has changed. 
In 1993, the Royal Commission on Criminal Justice recommended expanding the application of the current rule for defence disclosure on special fraud cases to all serious cases. Their rationale with respect to the possible infringement of the accused's rights was that they did not

believe that a requirement on the defence to disclose the substance of their case sooner rather than later infringes the right of defendants not to incriminate themselves. Where defendants advance a defence at trial it does not amount to an infringement of their privilege not to incriminate themselves if advance warning of the substance of such a defence has to be given. The matter is simply one of timing. We emphasize that under our proposals defendants may, if they choose, still stay silent throughout the trial."

This proposal would seem to have been adopted. Gil McKinnon, in his article ${ }^{32}$ and Suzanne Costom, in hers, ${ }^{33}$ make reference to a bill introduced in Parliament in November 1995, which was passed into law as the Criminal Procedure and Investigations Act 1996. This new law takes defence disclosure to a new level, codifying its procedure and setting out consequences for its absence. Under a system of "pre-trial discovery," both the Crown and the defence would provide the following in order:

[F]irst ... "primary prosecution disclosure." This is followed by compulsory disclosure by the accused of a "defence statement," which is a written statement "setting out in general terms the nature of the accused's defence," the "matters on which he takes issuc with the prosecution," and "in the case of each matter, the reason he takes issue with the prosecution." There is then "secondary disclosure by the prosecution" of "any prosecution material ... which might be reasonably expected to assist the accused's defence as disclosed." Section 10 of the Act deals with "faults in disclosure by the accused" and applies ... where an accused fails to give a defence statement to the prosecutor; where such defence statement is given in an untimely fashion; where the statement sets out inconsistent defences; or where a defendant puts forward at trial a defence other then that included in the statement. Where these or other "faults in disclosure by the accused" emerge, the court may "make such comments as appears appropriate...." The court or jury may also draw "such inferences that appear proper in deciding whether or not the accused is guilty of the offence concerned."

According to Clause $10(5)$ of the new $A c t$, and accused is not to be convicted solely on the basis of these inferences drawn by the Court. This procedure, as written, could be cause for some concern.

For example, in Canada, juries are unable to disclose any information relating to their deliberations. Section 649(b) of the Criminal Code makes any such disclosure a summary conviction offence. How, then, could the accused, or anyone, be assured of the fact that he or she was not convicted solely upon the basis of the adverse inference

Report of the Royal Commission on Criminal Justice, Cm. 2263 (1993), as quoted in Costom, supra note 29 at 82.

Supra note 15.

Supra note 29.

Supra note 29 at 83 [footnote omitted]. 
or the comments of the Court with respect to his or her failure to conform adequately to the pre-trial disclosure procedures? The simple answer is that no one can be so assured. A judge can provide the clearest, most succinct instructions imaginable to a jury; notwithstanding that, no one outside the jury deliberation room knows what causes them to reach their decision. In California, the state Supreme Court struck down a rule permitting the making of an adverse comment by both the Court and the prosecutor with respect to the accused's failure to testify. In Griffin v. California, ${ }^{35}$

The Court invalidated California's practice of permitting comment by both the court and the prosecutor on a defendant's failure to testify. The defendant faced no compulsion in terms of a penalty external to the trial process, such as imprisonment or an economic sanction, opcrating automatically upon his exercise of the right to remain silent. [The Court] analyzed the practice in terms of the burden it placed on the defendant's assertion of his right to remain silent. Thus, it held that a comment upon silence is invalid under the fifth amendment because it is a penalty imposed by courts for exercising a constitutional privilege. It cuts down on the privilege by making its assertion costly. ${ }^{36}$

All in all, it remains an extremely sensitive situation, one that could be found to be unfair to the accused. Or could it?

Could an adverse inference, drawn against an accused for failure to comply with pretrial disclosure, be found to be acceptable under the Charter? It would appear that it could. In $R$. v. François, ${ }^{37}$ the Supreme Court, in a 4-3 decision, supported the principle that "subject to the caveat that failure to testify cannot be used to shore up a Crown case which otherwise does not establish guilt beyond a reasonable doubt, a jury is permitted to draw an adverse inference from the failure of an accused person to testify." question with respect to the accused's right not to testify. It was argued on appeal that this suggested that the jury may have drawn such an adverse inference. This argument was rejected as it would require the appellate court to speculate as to what the jury did. $^{39}$

The trial judge did not specifically state that the jury could draw an adverse inference from the accused's failure to testify. This would have contravened section $4(6)$ of the Canada Evidence Act. ${ }^{40}$ However, permitting the jury to draw an adverse inference without instruction from the judge, or even allowing the possibility of that happening, would seem, on the face of it, to contravene the accused's right to silence. If a jury, without instruction from the judge on the subject, can be permitted to draw an adverse inference from the accused exercising one of his or her most basic legal rights, then perhaps it is not so unimaginable that a jury, properly instructed, could be permitted to draw an adverse inference from the accused's lack of compliance with

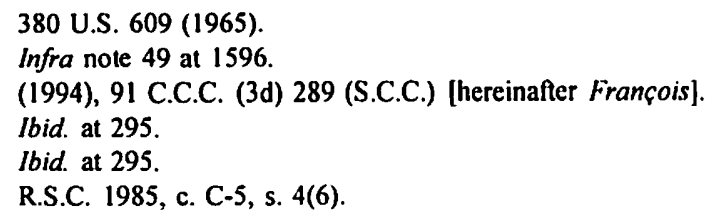


procedure, specifically, pre-trial defence disclosure. This would, however, be conditional upon clear, strict instructions from the trial judge that the burden of proving the guilt of the accused beyond a reasonable doubt must rest on the shoulders of the Crown, and that the jury must not convict upon the adverse inference alone.

In the United Kingdom, however, there is no Charter of Rights and Freedoms. ${ }^{41}$ It is, therefore, difficult to compare the protection of an accused's right against selfincrimination under such a system with the constitutional protection accorded it in Canada.

\section{B. Australia}

In Australia, which also does not have constitutional protection of legal rights, the 1992 Report of the Australian Institute of Judicial Administration (AIJA) recommended, for complex criminal trials, several changes designed to encourage greater defence disclosure:

- a meaningful pre-trial conference in which the defence would indicate the general areas in which the defence disputes the Crown's case, and any evidence that might be led;

- where the defence changes its position at trial, after the Crown has introduced a case on the basis of the defendant's position at the pre-trial hearing, the Crown would be entitled to split its case and call supplementary evidence in rebuttal;

- the defence would be given the option, at the opening of the trial, to make a brief statement after the Crown's opening address, outlining the issues to be contested, and the general defence. ${ }^{42}$

In June 1993 the Australian state of Victoria introduced a new set of procedures which include a codification of obligatory pre-trial defence disclosure. The state "government accepted some of the recommendations of the AIJA Report and rejected others." ${ }^{.43}$ Where an accused is committed for trial and the Crown requests disclosure from the defence, he or she must file in court and provide the prosecution with a notice disclosing the elements of the offence charged that are admitted and the elements of the offence charged that are not admitted, irrespective of whether or not a pre-trial hearing has been held ${ }^{44}$ The Crown is also permitted to call reply evidence to defence evidence that "could not reasonably have been foreseen by the prosecutor, having regard to the defence response served...." 45

Although there exists the European Convention on Human Rights, it is unclear whether or not this has any overriding effect on British legislation. This would be a possible avenue of further research. 
Where a pre-trial hearing is held, ${ }^{46}$ the judge may do a number of things, including order the prosecution and defence to disclose in writing, to the court and to each other, their respective cases. The defence response to the prosecution's case-statement must:

1. Indicate the facts and inferences contained in the prosecution case statement with which issue is taken;

2. be accompanied by copies of the statement of any expert witnesses whom the defence intends to call at the trial;

3. reply to any proposition of law stated in the prosecution case statement; and

4. contain a statement of any proposition of law on which the defence proposes to rely other than any general proposition of law relevant to all cases."

It would then appear that Canada is one of the last English-based common law countries in the Commonwealth with no procedure outlining pre-trial defence disclosure. This can easily be dismissed by the suggestion that England, Scotland, and Australia do not have constitutional protection of legal rights and civil liberties and that this lacuna allows them the legislative latitude to impose such schemes. This argument, however, tends to fail when one considers the example set by the United States.

\section{The United States of America}

The American Bill of Rights was drafted and introduced in 1789. It has many of the same protections accorded by the Canadian Charter of Rights and Freedoms. The two documents provide a number of the same civil liberties. Of primary importance for this paper, however, are the Fifth and Fourteenth Amendments to the Constitution of the United States. The "Fifth Amendment" is a wide-reaching clause that covers grand jury proceedings (an American alternative, in some instances, to a preliminary inquiry), "double jeopardy," self-incrimination, due process of law and deprivation of private property without just compensation. The Fourteenth Amendment extends the protection of these same rights to all citizens of the United States and obliges the individual states to conform to this protection.

The relevance of the Fifth Amendment to defence disclosure was first addressed by the United States Supreme Court in Williams v. Florida. ${ }^{48}$ Professor Robert P. Mosteller of Duke University addressed the issue of defence disclosure in the United States ${ }^{49}$ in the wake of Williams as follows:

First, the courts have all but written off the fifth amendment as providing any restriction upon discovery of information that the defendant may ultimately want to introduce at trial. The principal source of this development is the Supreme Court's decision in Williams v. Florida, which upheld the

This is done at the instance of the trial judge, the Crown, or the defence.

Crimes (Criminal Trials) Act 1993. s. 11, as cited in McKinnon, supra note 15 at 65.

399 U.S. 78 (1970) [hereinafter Williams]. This case addressed the constitutionality of Florida's rule requiring defence disclosure of an alibi defence, and the names and addresses of witnesses to be called in support of this defence, prior to trial.

R.P. Mosteller, "Discovery Against The Defense: Tilting The Adversarial Balance" (1986) Calif.

L. Rev. 1567. 
constitutionality of Florida's notice of alibi rulc. This decision has been interpreted as granting the states carte blanche to develop discovery rules that give the prosecutor an independent right to obtain even potentially incriminating information free from the strictures of the fifth amendment. ${ }^{\text {st }}$

Despite Professor Mosteller's negative views, the U.S. Supreme Court appears to see fit to allow defence disclosure. Suzanne Costom $^{\text {st }}$ dismisses the American example as being inapplicable in Canada. ${ }^{52}$ The major distinction that Maitre Costom draws is the "case-to-meet" rule.

In $R$. v. $P .(M . B .)^{53}$ the Supreme Court reiterated the principle that the accused cannot be conscripted against himself or herself to assist in his or her own prosecution. The court established that

[T]his means, in effect, that an accused is under no obligation to respond until the state has succeeded in making out a prima facie case against him or her. In other words, until the Crown establishes that there is a "case to meet", an accused is not compellable in a general sense (as opposed to the narrow, testimonial sense) and need not answer the allegations against him or her. ${ }^{\text {st }}$

While Maitre Costom insists that this is true in Canada, it is also true in the United States. Professor Mosteller asserts that certain, basic constitutional principles provide limits on defence disclosure. These include that

- The accused may not be required under discovery rules to make statements that the prosecution may use directly or derivatively in its case-in-chief.

- The accused's statements required by discovery rules may not be used to impeach his trial testimony, except when the discovery statement was willfully false or materially impeded adequate prosecutorial preparation. ${ }^{5 s}$

According to Mosteller, the Fifth Amendment prohibits the use of discovery of testimonial evidence that the State may use to establish its case-in-chief. Although this can be distinguished from the "case-to-meet" principle with respect to the timing of defence disclosure, it does not violate the principle with respect to the materials provided to the Crown. The Crown, under such a disclosure scheme, would still have to "meet its case" without the defence disclosure. This could be used to argue that since the Crown cannot make use of the defence disclosure in its case-in-chief, there is no reason to oblige the defence to provide it. Conversely, since the Crown cannot make use of the disclosure in its attempt to convict the accused, what harm is there in providing disclosure? These types of Lilliputian arguments could continue ad infinitum, but the principle to be gleaned from the American example remains: self-incrimination

Ibid. at 1571.

Supra note 29.

Ibid. at 84.

(1994) 89 C.C.C. (3d) 289 (S.C.C.).

Ibid. at 304.

Supra note 49 at $1572-73$. 
is not, as Maitre Costom claims, impeded by defence disclosure. The American practice is therefore not as inapplicable as she asserts.

It must be stated that Williams was decided on the basis of alibi evidence alone. The Court found that compulsory disclosure of alibi evidence was not, in essence, selfincriminating as the accused's defence was not "compelled within the meaning of the fifth amendment even though it may be the product of powerful forces bearing upon him." There is a similar "compulsion" in Canada. The accused, in accordance with the rule established in Cleghorn, , $^{56}$ is required to give "timely and adequate" notice of his or her intention to raise an alibi defence, accompanied by the consequence that should this notice not be given, the weight of the defence could be adversely affected.

Defence disclosure of other matters was more fully addressed by the California Supreme Court in Jones v. Superior Court of Nevada County. ${ }^{57}$ Jones, charged with rape, requested an adjournment in order to obtain medical evidence necessary to his defence. The adjournment ("continuance") was granted, but the prosecution wanted disclosure of the names and addresses of the witnesses he intended to call as well as the expert evidence itself. The Court ordered the disclosure on the basis that

while the state constitution's privilege against self-incrimination and the attorney-client privilege barred discovery of those documents and witnesses that the defendant did not intend to use at trial, discovery of witnesses and documents that the defendant did intend to use did not violate these privileges. ${ }^{5 \mathrm{k}}$

The Fifth Amendment, according to the rationale of Williams, protects the accused from being "compelled" to disclose information that may be self-incriminating. In determining the constitutionality of defence disclosure under the American practice, then, one must consider the nature of "compulsion." Professor Mosteller concludes that unconstitutional "compulsion" falls into two groups:

In the first group, the Supreme Court invalidates state practices because they threaten the defendant with sanctions external to the trial process, often for the purpose of producing testimonial assertions that may be used in a criminal prosecution. In the second group, there are no external sanctions; instead, operation of the rule impairs the defendant's fint amendment interests to a certain degrec. In this situation, the Court in some circumstances weighs the policies behind the fifth amendment right affected against the state's interest in the practice, or the Court may simply conclude that, employing a facially different treatment of the issuc, the practice "burdens" the exercise of the fifth amendment and therefore is necessarily unconstitutional. ${ }^{59}$

The "compelling state interest" test has been compared in Canadian constitutional jurisprudence to the first step of the Oakes test:" the "pressing and substantial interest" criterion. The "compelling state interest" test is used to mitigate violations of

Si. Supra note 2.

57 58 Cal. 2d 56 at 60,372 P.2d 919 (1962).

s* Supra note 47 at 1576.

59 Supra note 49 at 1592.

$(4)$

$R$ v. Oakes (1986), 24 C.C.C. (3d) 321 (S.C.C.). 
protected freedoms under the Bill of Rights. It is important to remember that the American Bill of Rights contains no interpretive clause, no section 1, as it were. But for jurisprudence to the contrary, these freedoms are quasi-absolute. If, before such a backdrop, defence disclosure is permitted and permissible, why would it not be so in Canada, where freedoms are routinely subjected to the caveat of section 1 of the Charter?

The scope of defence disclosure permitted in many of the United States is quite substantial..$^{61}$ Under an "independent right of discovery," eleven states provide that the accused is required to inform the prosecution of the nature of his defense.$^{62}$ Fourteen states and the District of Columbia require the defence to disclose names and addresses of all defence witnesses under an "independent right theory," ${ }^{63}$ and ten more states provide for such disclosure upon request for disclosure by the accused. ${ }^{64}$ The nature of the triggering request varies greatly. In Florida, Mississippi, Nebraska, Ohio, and Pennsylvania, disclosure of defence witnesses corresponds to a request by the accused for disclosure of prosecution witnesses. In New Jersey and Rhode Island, an accused may be required to disclose any "discoverable items," including witnesses, following a request for any type of disclosure. Wisconsin requires an accused wanting disclosure of prosecution witnesses to state, in writing, that he is willing to provide a list of his own witnesses to the prosecution. Iowa requires the accused to disclose witnesses only if the defence decides to request a deposition of government witnesses.

Twelve states give the prosecution an independent right to obtain the statements of all defence witnesses, ${ }^{65}$ and three more permit such disclosure to be obtained from the accused upon receipt of an appropriate request by him for disclosure. ${ }^{66}$ Moreover, the requirement that the accused reveal statements of witnesses he or she intends to call at trial is given a wide-ranging interpretation in a number of states: "The simplest of these expansions defines the term "statement" broadly to require the disclosure of not only written and recorded statements but also 'memoranda reporting or summarizing ... oral

The following footnoted information was obtained from C.E. Torcia, Wharton's Criminal Procedure, vol. 2, 13th ed. (Rochester, N.Y.: Lawyers' Cooperative Publishing, 1990), Mosteller, supra note 49 , and subsequent research.

Arizona, Arkansas, Colorado, Hawaii, lllinois, lowa (which is limited to defenses of alibi, insanity, intoxication, entrapment, and self-defense); Minnesota, Montana (which is limited to defenses of justifiable use of force, entrapment, compulsion, alibi, or absence of state of mind essential to offense); New Hampshire, New Jersey and Washington.

Arizona, Arkansas, Colorado, Hawaii, Idaho, lllinois, Massachusetts (where it is discretionary and contingent upon the prosecutor providing similar information), Minnesota, Missouri, Montana, New Mexico, The District of Columbia, Oregon, Vermont and Washington. Florida, lowa, Mississippi, Nebraska, New Jersey, Ohio, Pennsylvania, Rhode Island, West Virginia and Wisconsin.

Arizona, Hawaii (where statements recorded by defense counsel are excluded); Illinois, Massachusetts, (where discretionary and conditioned upon prosecution revealing similar information); Minnesota, Missouri, Montana, (where statements by defendants are also excluded); New Hampshire. New Mexico, The District of Columbia, (where statements by defendant to attorneys are excluded due to solicitor-client privilege), Oregon, Washington and Wisconsin (where statements normally disclosed after prosecution has presented its case but court may order disclosure at any time prior to trial upon showing of good cause). 
statements." create a written statement summarizing the testimony expected at trial or including the oral statements of its witnesses. ${ }^{68}$ Finally, five states permit the trial court to order disclosure from the defence of additional, unspecified materials and information upon a showing that it is "useful, important, or necessary for the prosecution adequately to prepare its case." 69

Given the range of information available under this "prosecutorial discovery of the defence," some applications of the rules are likely to require disclosure of incriminating information; for example, an accused's admission that he or she inflicted the injury, which is necessary when he or she provides notice of self-defense. As Professor Mosteller argues: ${ }^{70}$

[W] here incriminating information is required, the constitutionality of discovery under the fifth amendment will depend on the limitations imposed by those rules on when the prosecution may discover information from the defense and how it may use such information once obtained. The rules generally, however, impose few restrictions on prosecutorial discovery that address these concerns.

The defence seems universally required to provide disclosure of the defences it intends to raise and the names and addresses of witnesses only if it intends to present the defence or call these witnesses at trial. A number of states also include another, undefined, limitation, "subject to constitutional limitations." 71 Restrictions on the disclosure, by the defence, of medical and scientific reports vary somewhat between states.

The Federal Court system also requires a limited defence disclosure of certain materials. As Tanovich and Crocker state in their article:

Under R. 26.2 of the Federal Rules of Criminal Procedure, the defence must disclose to the prosecution any statements of witnesses after they have finished testifying in chicf. Rule 26.2(a) was adopted by the Supreme Court following United States $v$. Nobles. "The statements must relate to the witnesses' testimony. Under R. 16, there is reciprocal discovery for the following real evidence: books, papers, documents, photographs and tangible objects and the results and reports of physical or mental examinations and of scientific tests or experiments. ${ }^{73}$

Mosteller, supra note 49 at 1581.

Specifically, New Jersey, Rhode Island and Washington.

Arizona, (where a "substantial need in the preparation" of the state's case and an inability "without undue hardship to obtain the substantial equivalent by other means"), Illinois, ("upon a showing of materiality [...] and if the request is reasonable"), Missouri, (where a "reasonable" request for discovery that is "relevant and material to the state's case"), Montana (a "substantial need, [..] unable without undue hardship to obtain the substantial equivalent by other means, $[\ldots]$ will not violate the accused's constitutional rights"), and Utah (with "good cause shown [...] in order for the prosecutor to adequately prepare his case").

Supra note 49 at 1582.

Arkansas, Colorado, Illinois, Mississippi and Missouri.

422 U.S. 225 (1975).

Supra note 8 at 345. 
Also under the Federal Rules, the defence must disclose, prior to trial, notice of either an alibi (accompanied by the names and addresses of witnesses the defence intends to call in support of the alibi) or an insanity defence (accompanied by a notice of intent to introduce expert testimony in relation to a mental disorder or defect or any other mental condition suffered by the accused which may have a bearing on his or her guilt).

The experience in California with respect to defence disclosure provides an interesting template for Canada. From 1970 to 1990 , the state courts prohibited a rule that would require defence disclosure, on the ground that it ran afoul of the "compulsion" prohibition contained in the interpretation of the privilege against selfincrimination as enunciated in the California Constitution. Following this period, in June 1990, Californians voted, in a referendum on Proposition $1 / 5$, to amend their state Constitution by adding a clause to provide for defence disclosure in criminal matters ("reciprocal discovery"). Following the results of the referendum, the California Legislature amended the Penal Code by adding sections setting out the procedure to follow by the prosecution and by defence with respect to disclosure. ${ }^{74}$ The new sections state that one of the purposes of pre-trial disclosure is "to promote the ascertainment of truth in trials by requiring timely pre-trial discovery."

An accused is now required to disclose to the prosecution the names and addresses of prospective witnesses, other than the defendant, together with any relevant written or recorded statements of those persons, expert reports and the results of any physical or mental examinations, scientific tests, experiments or comparisons which the defence intends to introduce. ${ }^{76}$ This disclosure is to be provided at least 30 days prior to trial. There is a continuing obligation on both the prosecution and the defence to immediately disclose any new information to be used by them at trial that comes into their knowledge or possession within the 30 -day period prior to trial. ${ }^{77}$

This process encourages the parties to make disclosure informally: "It is only if one of the parties fails to comply within 15 days of receiving a request that the other party can seek a court order enforcing disclosure." 78 The powers of which the court disposes, in the event of non-compliance, are quite broad. They include holding the parties in contempt, "delaying or prohibiting the testimony of a witness or the presentation of real evidence, an adjournment, and advising the jury of any failure or refusal to disclose. The court may prohibit the testimony of a witness only if all other sanctions have been exhausted."79

In his article, Davison rejects many of the "modest proposals" presented by Tanovich and Crocker as being too heavily influenced by American examples. He states that the "arguments for defence disclosure in any greater measure than is presently required

Tanovich \& Crocker, supra note 8 at $344-45$.

California Penal Code. s. 1054.7.

Ibid., s. 1054.3(a), as reproduced in Tanovich \& Crocker, supra note 8 at 345.

lbid., s. 1054.7, as reproduced in Tanovich \& Crocker, supra note 8 at 347.

Ibid.

Ibid., as reproduced in Tanovich \& Crocker, supra note 8 at 347. 
under our law, should, as with so many other aspects of procedure and practice, be left south of the border and not imported into this country."80 However, he provides several examples of where defence counsel is "pressured" (be it lightly or otherwise) into providing advance notice of any "special defences" that may be raised. He refers to the conduct of pre-trial conferences held under the provisions of section 625.1 of the Criminal Code. He states that

In fact, during most pre-trial conferences in which the writer has been involved, under the guise of wanting to be able to tell the trial judge of any "special" areas which will have to be left with the jury, defence counsel is usually also quizzed about any "special defences" to be raised, such as entrapment, insanity, self-defence, and so on. The constitutional validity of attempting to indirectly impose such disclosure obligations upon the defence has not yet been tested."

His reference to the lack of a constitutional challenge to this provision begs the question: Why not? If the notion of defence disclosure is so repugnant to the principle against self-incrimination, any pressure, be it light or otherwise, should be challenged. Any questions relating to defences to be raised, ulterior issues to be brought up, any questions that may impede the accused's right to remain silent and to avoid selfincrimination should be met with either silence or a plain refusal to answer. If, however, these questions are routinely answered merely in the guise of expediency or deference to judicial authority, any argument presented against pre-trial defence disclosure is weakened by this current practice. One would presume that defence disclosure is an either/or prospect: either it is acceptable and "introduceable," or it is not. To publicly denounce the concept while privately acquiescing to its (albeit limited) practice is nothing short of bizarre.

Maitre Costom says, seems to fall victim to this dichotomy as well. After categorically stating that she has "not found any of the arguments in favour of imposing a mandatory duty on defence counsel to disclose their case to the Crown prior to trial compelling,"82 she concludes by stating that "voluntary disclosure by defence counsel should be encouraged [... and indeed] disclosure to the prosecution can often benefit the accused."83 As stated above, it may simply be that the use of the terms "mandatory" and "disclosure" in close proximity to one another is what causes an immediate negative reaction, and not necessarily the concepts themselves.

\section{Conclusion: Proposals for Defence Disclosure}

In light of the practice in the other Commonwealth jurisdictions and in the United States, it would seem that defence disclosure is not as unthinkable as certain authors would have people believe. As stated above, notice is already required - and apparently constitutionally supported - with respect to many aspects of the defence's case. It would not appear that a moderate expansion of these requirements would in any 
way bring harm to the accused, his or her defence, nor would it appear to greatly infringe upon the accused's Charter rights.

Should the Canadian judicial system introduce defence disclosure requirements, it would do well to learn from the examples of the jurisdictions listed above. For example, under Scottish law, an accused may be required to submit to an examination, in the presence of his or her counsel, by the Crown prior to trial. This, in Canada, would not be constitutionally sound. The accused must be allowed to maintain his or her right to pre-trial silence in a testimonial sense. The accused cannot be required to "testify" prior to trial, and have that "testimony" hang over his or her head.

However, other Scottish practices, coupled with general practices in the United Kingdom, have some merit. Once Crown disclosure has been provided, the defence may be required to provide the "general terms the nature of the defence, the parts of the Crown's case objected to, and any questions of law which will be raised." ${ }^{84}$ This would appear to be permissible under the Charter. In Dwernychuk, ${ }^{85}$ reasonable notice of a Charter-based defence was required, and the leave to appeal the decision to the Supreme Court was refused. As argued above, if notice of a Charter-based defence is permissible, notice of a general, affirmative defence would also appear to be permissible. Some defences are either as involved or more involved than Charter applications. It can be argued that such disclosure is not an infringement of an accused's right against self-incrimination due to the meaning of the term "defence." If the information provided serves only to cause the accused to be acquitted of the charge against him or her (or to reduce the charge to a lesser, included offence), how can it be incriminating? It would then also appear that, like alibi notice, this would be a reasonable limitation on the accused's right to pre-trial silence.

The disclosure of any questions of law which will be raised at trial seems also to fall under the umbrella of the Dwernychuk decision. Granted, a Charter-based defence or application can be seen as being more than a mere "question of law," but, if a question of law can be more adequately raised and dealt with by an informed judge and prosecutor, then one could reasonably conclude that it would be in the best interests of the accused that notice be given. It cannot be seen as a given that judges will always rule against the accused should they have time to research a point of law. If this were the case, the defence counsel would merely be attempting to pull the wool over the eyes of the Court by surprising the judge and prosecutor with an arcane interpretation of a point of law. Better informed and prepared advocates and judges could only result in less appeals on errors of law, and less confusion by participants in the litigation process when a complex issue is raised.

The "parts of the Crown's case objected to" is not necessarily an easy question to address. In a guilty plea, the accused routinely admits the Crown's facts, but the converse is not always true; the accused does not always reject all of the Crown's facts when the plea is not guilty. The nature of the defence to be raised may preclude any 
premature admission of certain of the Crown's facts, but it would also appear that disclosure of the defence(s) to be raised at trial would make obvious those of the Crown's facts that the accused intends to contest. However, it would be wiser to err on the side of the accused's rights than to speculate as to whether such disclosure would impede the presentation, or at least the full presentation, of a particular defence. Limiting adoption of the United Kingdom practices to disclosure of the nature of the defences to be raised and the questions of law to be addressed at trial would appear to be sufficient.

With respect to the arguably more pertinent American example, defence disclosure in Canada would not be able to follow the same wide path that has been tread south of the border. The requirement that the Crown "meet its case" prior to disclosure by the defence would appear to infringe somewhat on such a wide-reaching scheme. Although one could easily disagree with the interpretation given of the "case to meet" rule as enunciated by Maitre Costom an adoption of the rules with respect to expert evidence and witness lists would appear not to violate the accused's right against selfincrimination.

An accused cannot incriminate himself or herself by the testimony of a third party: this would appear to be the role of the Crown's witnesses. If an expert were to testify on the accused's behalf and then appear, under cross-examination, to adopt a position unfavourable to the defence, this would not be the fault of the accused. The accused cannot be compelled to present the expert's testimony. If an accused presents an affirmative defence and it backfires, the defence can hardly claim that the accused's Charter rights have been violated. If an accused is forced to present a defence, it would likely be due to the strength of the Crown's case and not due to a disclosure requirement. Furthermore, if a mandatory defence disclosure rule were introduced in Canada, it could reasonably be conceived in the same manner as those requirements stated by Professor Mosteller with respect to the basic constitutional notions of the American Fifth Amendment:

- The defendant may not be required under discovery rules to make statements that the prosecution may use directly or derivatively in its case-in-chief,

- The defendant's statements required by discovery rules may not be used to impeach his trial testimony, except when the discovery statement was willfully false or materially impeded adequate prosecutorial preparation. ${ }^{86}$

If these rules were followed, and the Crown were made to follow them by means of sanctions or reprimands, there would be no jeopardy placed upon the accused were he or she required to provide pre-trial disclosure. As stated above, the accused can always remain silent and offer no defence at all to the charges. In this regard, the accused's right to pre-trial silence is absolute. 
How could a scheme of defence disclosure be introduced? Logically, the federal government, under the "criminal power," ${ }^{17}$ has jurisdiction over criminal procedure. However, under the Province of Alberta Court of Queen's Bench Rules for Pre-Trial Conferences under Subsection 553.1(2) of the Criminal Code ${ }^{88}$ pre-trial conferences are designed to "require both sides to inform the presiding justice of 'the nature and particulars of any preliminary motion that they intend to make." "89 It is conceivable that the Courts themselves could introduce rules requiring defence disclosure under the auspices of a pre-trial conference. However, any such approach could limit the requirements of defence disclosure to those trials requiring pre-trial conferences. At present, under section 625.1(2), the only trials requiring "pre-hearing conferences" are jury trials. Therefore, any rules imposed by the courts under their rules would be limited to jury trials, where, under the federal power, disclosure could be required for all trials.

Notwithstanding any requirements placed upon the defence to disclose elements of its case, any "mandatory" requirements must be accompanied by reciprocal, "mandatory" requirements placed upon the Crown. Currently, Parliament is debating Bill C- $-46,{ }^{90}$ which would codify the rules for disclosure of third-party documents. If a law were to be passed codifying a burden to be placed on the defence, it would be unfair not to place an equal statutory burden upon the Crown. Any disclosure made by the defence is based upon the information provided to it by the Crown. All other independent defence information can only come from the accused; this information is and must remain covered by solicitor-client privilege.

There is the possibility that the Provincial Courts could have a certain control over this "disclosure" through its own, internal rules. With respect to the Provincial Courts, in Dwernychuk, the Alberta Court of Appeal stated of the procedure to be followed with respect to defence notice of an eventual Charter-based application, that

[i]n the Court of Queen's Bench the accused has had an opportunity to have a preliminary inquiry, the Crown has made full disclosure either voluntarily or pursuant to an order of the court, and there will have been a pre-trial conference (at least in jury cases). Defence counsel will usually know whether there are grounds upon which an application to exclude the evidence might be successful. The same may not be the case in the Provincial Court, where the case may proceed to trial without the defence having had the same opportunities to explore potential Charter issues before trial. Therefore, in the Provincial Court procedures may be different, but the spirit of the points made here should nevertheless prevail. The Provincial Court of Alberta is, of course, free to set its own practice on this point."'

If the Provincial Court has the jurisdiction to require defence notice of Charter-based applications, could the Provincial Court, which handles the majority of criminal cases

(U.K.), 30 \& 31 Vict., c. 3, s. 9l(27).

SI/TR 86-79.

Davison, supra note 6 at 106.

The election writ issued 27 April 1997 for June 21997 has caused this bill to dic on the order paper.

Supra note 23 at 400. 
in Alberta, have the jurisdiction to require defence notice of any other elements of the defence's case? Recently, in R. v. Habhab, Judge Wendon of the Edmonton Provincial Court dealt with the establishment of a Dwernychuk procedure in the Provincial Courts. He stated that

[i]t is to be pointed out however, that nowhere does it state there ought not to be an established procedure in the Provincial Court when there is an application under s. 24(2) to exclude evidence. A lack of a preliminary hearing or a pretrial conference, in which potential Charter issues may be explored, and/or decided upon is the reason usually given. In Edmonton at least, many accused waive their right to a preliminary hearing. Presumably this does not hamper their ability to bring applications to exclude evidence under 24(2), at trial in the Court of Queens Bench. Furthermore, in the Provincial Court in Edmonton and elsewhere, there are pre-trial conferences held for trials of a certain duration. The conferences are scheduled well before the trial. It would seem to me that this would be an opportune time to discuss any issues that might arise as a result of an application under s. 24(2). A frank discussion of the issue would alert and assist the trial judge.

As stated above, Crown disclosure in the Provincial Court has developed to the point where defence counsel are able to make effective use of it in trying their cases. As well, the requirement for notice is being observed. If the spirit of the points made in Dwernychuk is to prevail, in my view, counsel presently have ample opportunity, and enough information at their disposal to be able to advise the court with reasonable particularity not only the evidence that they anticipate they will call in support of the allegation, but as well, what witnesses will be required. If this is done, it will become easier for the Court, with the assistance of counsel, to decide upon the procedure that is to be used in the application to exclude evidence under s. 24(2) of the Charter."

Judge Wendon made reference to the use of pre-trial conferences. This was discussed earlier as the procedure under section 625.1 of the Criminal Code. As Davison mentioned in his article, this is normally where informal notice is given to the Crown and to the Judge with respect to the direction of the defence's case. Although these conferences are only "required" under the Code in jury trials, the procedure of the Provincial Courts in Alberta is to hold them in cases that are thought will last longer than half a day. If this is a procedure that has been set internally by the Provincial Courts, it is suggested that the Courts could, during these conferences, also establish a requirement for notice of certain aspects of the defence's case that will be presented at trial. ${ }^{93}$

In conclusion, defence disclosure cannot be seen as a plague by defence counsel in the same way that it cannot be seen as a panacea by Crown counsel. It must be viewed only as a balancing of the evidentiary burden placed upon the Courts, and not as a hurdle to be overcome by the accused in his or her defence. Defence disclosure will

"2. $\quad$ R. Habhab [1997] A.J. No. 175, at paras. 35 and 36.

"Section 19.1(2)(b) of the Provincial Court Act (1996 c. 28, s. 37) allows the Provincial Court to "modify the Alberta Rules of Court as necded." It remains unclear, however, in light of the federal criminal procedure power under s. 91(27), whether this power could be used to oblige defence counsel to give notice at a pre-trial conference. The Court can establish its own procedure, but does this ability allow them to fundamentally change criminal procedure as it currently exists? I would suggest that this could only be settled by the Supreme Court. 
eventually be introduced in Canada. This is more of a political reality than a legal or jurisprudential one. Current sentiment with respect to victim's rights, with respect to the Charter being used more to "protect the accused" than to "protect the victim" is, while based on ignorance of fundamental justice and the presumption of innocence, impossible to ignore. In 1970, the American Bar Association adopted a series of "standards" that were designed to facilitate defence disclosure. This was done immediately after the decision of the Supreme Court in Williams v. Florida. Was it a pre-emptive strike to avoid legislative compulsion? Perhaps. Would Canadian defence counsel be far better off were they to introduce their own guidelines with respect to defence disclosure prior to it being legislated upon them? Definitely. Put it this way: would defence counsel prefer to play their game by their own rules, or would they rather the opposing team draft up a set for them? 